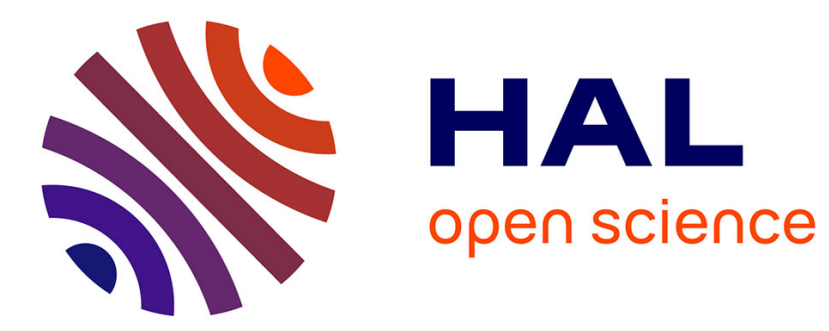

\title{
The endocrine profile of subcutaneous and visceral adipose tissue of obese patients
}

M. Dolinková, I. Dostálová, Z. Lacinová, D. Michalský, D. Haluzíková, M. Mráz, M. Kasalický, M. Haluzík

\section{- To cite this version:}

M. Dolinková, I. Dostálová, Z. Lacinová, D. Michalský, D. Haluzíková, et al.. The endocrine profile of subcutaneous and visceral adipose tissue of obese patients. Molecular and Cellular Endocrinology, 2008, 291 (1-2), pp.63. 10.1016/j.mce.2008.05.001 . hal-00532025

\section{HAL Id: hal-00532025 \\ https://hal.science/hal-00532025}

Submitted on 4 Nov 2010

HAL is a multi-disciplinary open access archive for the deposit and dissemination of scientific research documents, whether they are published or not. The documents may come from teaching and research institutions in France or abroad, or from public or private research centers.
L'archive ouverte pluridisciplinaire HAL, est destinée au dépôt et à la diffusion de documents scientifiques de niveau recherche, publiés ou non, émanant des établissements d'enseignement et de recherche français ou étrangers, des laboratoires publics ou privés. 


\section{Accepted Manuscript}

Title: The endocrine profile of subcutaneous and visceral adipose tissue of obese patients

Authors: M. Dolinková, I. Dostálová, Z. Lacinová, D. Michalský, D. Haluzíková, M. Mráz, M. Kasalický, M. Haluzík

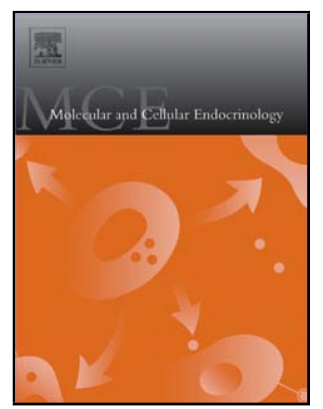

PII: S0303-7207(08)00204-9

DOI: doi:10.1016/j.mce.2008.05.001

Reference: MCE 6872

To appear in: $\quad$ Molecular and Cellular Endocrinology

Received date: $\quad 10-1-2008$

Revised date: $\quad 31-3-2008$

Accepted date: $\quad 4-5-2008$

Please cite this article as: Dolinková, M., Dostálová, I., Lacinová, Z., Michalský, D., Haluzíková, D., Mráz, M., Kasalický, M., Haluzík, M., The endocrine profile of subcutaneous and visceral adipose tissue of obese patients, Molecular and Cellular Endocrinology (2007), doi:10.1016/j.mce.2008.05.001

This is a PDF file of an unedited manuscript that has been accepted for publication. As a service to our customers we are providing this early version of the manuscript. The manuscript will undergo copyediting, typesetting, and review of the resulting proof before it is published in its final form. Please note that during the production process errors may be discovered which could affect the content, and all legal disclaimers that apply to the journal pertain. 


\section{The endocrine profile of subcutaneous and visceral adipose tissue of obese}

\section{patients}

${ }^{1}$ Dolinková M., ${ }^{1}$ Dostálová I., ${ }^{1}$ Lacinová Z., ${ }^{2}$ Michalský D., ${ }^{1,3}$ Haluzíková D., ${ }^{1}$ Mráz M., ${ }^{2}$ Kasalický M. and ${ }^{1}$ Haluzík M.

${ }^{1} 3$ rd Department of Medicine, ${ }^{2}$ Department of Surgery and ${ }^{3}$ Department of Sports Medicine, 1st Faculty of Medicine, Charles University and General University Hospital, Prague, Czech Republic

\section{Corresponding author:}

Martin Haluzik, Prof, MD, PhD

$3^{\text {rd }}$ Department of Medicine, $1^{\text {st }}$ Faculty of Medicine

U Nemocnice 1

12808 Prague 2

Czech Republic

Tel.: + 420224962908

Fax: +420224919780

e-mail: mhalu@lf1.cuni.cz

Key words: obesity; metabolic syndrome; subcutaneous adipose tissue; visceral adipose tissue; isolated adipocytes; gene expression. 


\section{SUMMARY}

The aim of the present study was to evaluate the expression profile of genes potentially related to metabolic complications of obesity in the whole adipose tissue and isolated adipocytes from subcutaneous (SAT) and visceral adipose tissue (VAT) from twelve nondiabetic obese women and twelve lean women. Real-time polymerase chain reaction was used for expression analysis of 41 genes of interest and two housekeeping genes. We found increased expression of specific proinflammatory and adipogenic genes and reduced expression of specific lipogenic and insulin signaling pathway genes in obese relative to lean women with no preferable localization in SAT or VAT depot. The gene expression significantly differed between adipocytes and adipose tissue but both contributed to the proinflammatory profile in obesity. We conclude that both SAT and VAT exhibit alterations in the expression of specific genes possibly contributing to proinflammatory and insulin resistance state and consequently to metabolic complications of obesity. 


\section{INTRODUCTION}

The global increase in the prevalence of obesity and its associated comorbidities commonly refered to as metabolic or insulin resistance syndrome has stimulated intensive research focused on the better understanding of energy metabolism regulation and the possibilities to prevent and/or treat obesity. Numerous large scale studies have demonstrated that the presence of metabolic syndrome markedly increases cardiovascular morbidity and mortality (Frayn and Coppack, 1992; Eckel et al., 2005 and Fujita et al., 2006).

During the last decade, a lot of new knowledge has been gained in this field, including the discovery of endocrine function of adipose tissue (Hotamisligil et al., 1993 and Zhang et al., 1994). It is now generally accepted that adipose tissue secretes a variety of factors that exert numerous paracrine and endocrine effects and play an important role in metabolic regulations (Fasshauer et al., 2001 and Eckel et al., 2005). The human white adipose tissue is now recognized as a central player in the sublinical inflammatory state that is characteristic for patients with obesity and insulin resistance or metabolic syndrome. Obesity enhances adipocyte size and significantly alters its endocrine characteristics towards more proinflammatory and insulin resistance-inducing factors production. Furthemore, obesity is accompanied by markedly increased infiltration of adipose tissue with immunocompetent

cells that in turn produce increased amounts of proinflammatory factors such as tumor necrosis factor-alpha (TNF- $\alpha$ ), interleukin-6 (IL-6), resistin and many others (Bastard et al., 2006 and Matsuzawa, 2006).

Numerous clinical studies have demonstrated that important differences exist with respect to endocrine production of different adipose tissue depots. In particular, visceral adipose tissue and epicardial adipose tissue appears to have more proinflammatory and metabolically harmful profile according to most but not all studies (Abate et al., 1995; Wajchenberg, 2000; Wagenknecht et al., 2003 and Kremen et al., 2006). 
Although a lot of new knowledge has been gained with respect to the role of adipose tissue in human physiology the studies of the wide-ranging gene profile in the subcutaneous and visceral adipose depots of obese subjects have been limited and bring up some controversies. Most gene expression studies have been performed on whole adipose tissue and the expression of a very restricted number of genes has been quantified in human studies (Tan et al., 2005 and Kolak et al., 2007). Thus, the aim of the present study was to evaluate an expression profile of genes potentially related to metabolic complications of obesity in the samples of whole adipose tissue and isolated adipocytes from both subcutaneous (SAT) and visceral adipose tissue (VAT) depots from obese insulin resistant patients and normal-weight healthy subjects.

\section{METHODS}

\section{Study subjects}

Twelve non-diabetic obese women (mean age, $44.9 \pm 2.7 \mathrm{yr}$; mean body mass index, 41.0 $\pm 1.9 \mathrm{~kg} / \mathrm{m}^{2}$ ) and twelve normal-weight age-matched control women (mean age, $48.9 \pm 2.6 \mathrm{yr}$; mean body mass index, $23.6 \pm 0.7 \mathrm{~kg} / \mathrm{m}^{2}$ ) were included in the study. None of the subjects suffered from diabetes (defined as fasting plasma glucose $>7.0 \mathrm{mmol} / \mathrm{l}$ ). Seven out of twelve obese subjects had impaired fasting glucose (between 5.6 to $6.9 \mathrm{mmol} / \mathrm{l}$ ), the subjects with diabetes have been excluded from the study. All women included in the study were hospitalized at the General University Hospital, Prague. The samples of subcutaneous and visceral adipose tissue were obtained from the abdominal region during gastric banding surgery in obese patients and elective cholecystectomy in control women. Body weight of studied patients remained stable for at least 3 months prior the study. None of the patients had malignant tumor, thyroid disease, or acute infectious disease. Control subjects had no history of obesity and/or diabetes. Written informed consent was signed by all participants before 
being enrolled in the study. The study was approved by the Human Ethical Review Committee, First Faculty of Medicine, and General University Hospital, Prague, Czech Republic, and was performed in accordance with the guidelines proposed in the Declaration of Helsinki.

Anthropometric examination, blood sampling and adipose tissue sampling

Anthropometric examination of all subjects was performed one day before the operation. All subjects were measured and weighted, and body mass index was calculated. Blood samples for biochemical and hormonal measurements were withdrawn between 07:00 $\mathrm{h}$ and 08:00 $\mathrm{h}$ after an overnight fasting at basal state (at the day of operation before the start of anesthesia). Serum was obtained by centrifugation and the samples were subsequently stored in aliquots at $-70^{\circ} \mathrm{C}$ until further analysis.

Samples of subcutaneous and visceral adipose tissue for mRNA expression analysis were obtained from abdominal region at the beginning of surgery. All samples were taken from approximately the same localization. The samples were obtained from the tissue that has not been previously traumatized mechanically or by cauterization to avoid of the influence of local tissue damage on studied parameters. The tissue samples were collected to RNA stabilization reagent (RNAlater, Qiagen, Hilden, Germany) and stored at $-80^{\circ} \mathrm{C}$ until further processing.

\section{Hormonal and biochemical assays}

Serum adiponectin was measured by commercial RIA kit (Linco Research, St. Charles $\mathrm{MO}$ ) and C-reactive protein (CRP) was measured by high sensitive assay (high sensitive CRP - hsCRP) (Diagnostic Systems Laboratories Inc, Webster, TX). Sensitivity was $1.0 \mathrm{ng} / \mathrm{ml}$ for adiponectin and $1.6 \mathrm{ng} / \mathrm{ml}$ for hsCRP. Intra- and interassay variability for the kits were $<5 \%$ 
and $9.3 \%$, respectively. Serum leptin and resistin concentrations were measured by commercial ELISA kit (BioVendor, Brno, Czech Republic). Sensitivity was $0.2 \mathrm{ng} / \mathrm{ml}$ for resistin and $0.12 \mathrm{ng} / \mathrm{ml}$ for leptin, and the intra- and interassay variability were $<5 \%$ and $8.0 \%$, respectively. Blood glucose was measured on an ABL 700 analyzer (Radiometer Medical A/S, Copenhagen, Denmark). Serum insulin concentrations were measured by commercial RIA kit (Cis Bio International, Gif-sur-Yvette Cedex, France). Sensitivity was 2.0 $\mu \mathrm{IU} / \mathrm{ml}$ and the intra- and interassay variability were $4.2 \%$ and $8.8 \%$, respectively.

Biochemical parameters were measured in the Department of Biochemistry of General University Hospital by standard laboratory methods. Homeostasis model assessment (HOMA-IR) index was calculated as previously described (Matthews et al., 1985) using the following formula: fasting serum insulin $(\mathrm{mIU} / \mathrm{l}) \mathrm{x}$ fasting serum glucose $(\mathrm{mmol} / \mathrm{l}) / 22.5$.

\section{Adipocyte isolation}

Immediately after removal $\sim 1 \mathrm{~g}$ of adipose tissue was transferred to $5 \mathrm{ml}$ of sterile $37^{\circ} \mathrm{C}$ KRBHA solution with glucose and bovine albumin $(118.5 \mathrm{mM} \mathrm{NaCl}, 4.75 \mathrm{mM} \mathrm{KCl}, 2.70$ $\mathrm{mM} \mathrm{CaCl}_{2}, 1.19 \mathrm{mM} \mathrm{KH}_{2} \mathrm{PO}_{4}, 1.09 \mathrm{mM} \mathrm{MgSO}_{4} .7 \mathrm{H}_{2} \mathrm{O}, 25 \mathrm{mM} \mathrm{NaHCO} 3,5 \mathrm{mM}$ glucose and $3.33 \%$ bovine albumin). Within $10 \mathrm{~min}$, samples were dissected to smaller sections and transferred to $5 \mathrm{ml}$ sterile KRBHA medium with $0.3 \%$ collagenase type VIII (from Clostridium histolyticum, Sigma-Aldrich, Germany) and incubated in $37{ }^{\circ} \mathrm{C}$ shaking at 120 RPM for 35 min. After enzymatic digestion, the undigested tissue was separated by filtration through the nylon mesh of $250 \mu \mathrm{m}$ pore size (Spectrum Laboratories, Inc., CA, USA). Floating adipocyte layer was washed three times with $37^{\circ} \mathrm{C}$ sterile $\mathrm{KRBHA}$ medium without collagenase. RNA was immediately extracted from isolated adipocytes on MagNA Pure instrument using MagNA Pure Compact RNA Isolation (Tissue) kit (Roche Diagnostics GmbH, Germany) (see bellow). 


\section{Determination of $m R N A$ expression}

Approximately $100 \mathrm{mg}$ of tissue was collected to $1 \mathrm{ml}$ of RNA stabilization reagent (RNAlater, Qiagen, Germany) and stored at $-80{ }^{\circ} \mathrm{C}$ until further analysis. Samples of subcutaneous and visceral adipose tissue were homogenized on a MagNA Lyser Instrument using MagNA Lyser Green Beads (Roche Diagnostics GmbH, Germany). Total RNA was extracted from the homogenized sample on MagNA Pure instrument using MagNA Pure Compact RNA Isolation (Tissue) kit (Roche Diagnostics GmbH, Germany). The RNA concentration was determined from absorbance at $260 \mathrm{~nm}$ (BioPhotometer, Eppendorf AG, Germany). All samples had a 260/280 nm absorbance ratio $1.78 \pm 0.06$. The integrity of the RNA was checked by visualization of $18 \mathrm{~S}$ and $28 \mathrm{~S}$ ribosomal bands on $1 \%$ agarose gel with an ethidium bromid. $1 \mu \mathrm{g}$ of total RNA was used for reverse transcription to synthesize the first strand cDNA using the oligo $(\mathrm{dT})_{18}$ primers following the instructions of the RevertAid First Strand cDNA synthesis kit (Fermentas Life Science, Lithuania).

Measurement of gene expression was performed on an 7900HT Fast Real-Time PCR System instrument (Applied Biosystems, Foster City, CA, USA) using TaqMan ${ }^{\circledR}$ Custom Array. For reaction was used a mix of $\operatorname{TaqMan}^{\circledR}$ Universal PCR Master Mix, NO AmpErase ${ }^{\circledR}$ UNG (Applied Biosystems, Foster City, CA, USA), nuclease-free water (Fermentas Life Science, Lithuania) and approximately $12 \mu \mathrm{g}$ of cDNA sample.

Controls with no cDNA template were performed with each assay and all samples were run at least in duplicates. The increase in fluorescence was measured in real time and data were obtained as threshold cycle $\left(\mathrm{C}_{\mathrm{T}}\right)$ values. To compensate for variations in input RNA amounts and efficiency of reverse transcription, $\beta$-2-microglobulin (B2M) and 18S rRNA were used as an endogenous references and results were normalized to the means of these 
values. Relative expression of genes was calculated using the formula $2^{-\Delta \Delta \text { (CT cytokine-CT reference }}$ gene).

\section{Statistical analysis}

The statistical analysis was performed on SigmaStat software (SPSS Inc., Chicago, IL). The anthropometric, biochemical and hormonal results are expressed as means \pm SEM. Differences of gene expression and serum parameters between obese and non-obese were evaluated using unpaired $t$ test or One Way ANOVA as appropriate. Statistical significance was assigned to $\mathrm{P}<0.05$.

Expression levels of the genes of interest are in arbitrary units and are normalized to two housekeeping genes 18S rRNA and $\beta$-2-microglobulin (B2M). The fold changes of the mRNA expression of genes of interest in obese (relatively to non-obese group) were calculated. The mean value of mRNA expression for each gene of interest in non-obese group was taken as 1.0 .

\section{RESULTS}

Anthropometric, biochemical and hormonal characteristics of the patients

Anthropometric, biochemical and hormonal characteristics of the patients are summarized in Table 1. As expected, obese patients had markedly increased body mass index, C-reactive protein, fasting serum insulin and glucose levels and significantly increased homeostasis model assessment index of insulin resistance. Glycated hemoglobin, total cholesterol and fasting serum triaglycerides did not differ between the groups. Serum leptin levels were markedly increased while serum adiponectin levels were significantly decreased in obese relative control group. Serum resistin did not significantly differ between the groups. 
Identification of differentially expressed genes between obese patients and normal-weight women

From a total number of 41 genes studied, we identified 14 genes with significantly different expression between obese and control subjects. The complete summary of the fold changes in the gene expression in VAT and SAT and isolated adipocytes from both depots in obese relative to non-obese is shown in Table 2.

In the isolated adipocytes from SAT, we found markedly increased chemokine C-C motif ligand 3 (CCL3) and c-fos-induced growth factor expression and significantly reduced expression of fatty acid synthase (FASN), peroxisome proliferator-activated receptor alpha (PPAR- $\alpha$ ), faciliated glucose transporter, member 4 (GLUT4), sterol regulatory element binding transcription factor 1 (SREBF1) and vascular endothelial growth factor (VEGF) in obese patients compared with control subjects. Interleukin-10 (IL-10) and resistin were undetectable in adipocytes from both VAT and SAT in the both groups of subjects.

In the isolated adipocytes from VAT, we found significantly decreased gene expression of adiponectin, uncoupling protein 2 and VEGF and markedly increased expression of vascular endothelial growth factor C (VEGFC) in obese patients compared with control subjects. IL-10, TNF- $\alpha$ and resistin were undetectable in adipocytes from both VAT and SAT in both studied groups.

In the whole SAT, we found significantly increased expression of angiopoietin 2 and significantly decreased expression of FASN, GLUT4 and SREBF1 in obese relative to lean subjects.

In the whole VAT, we found marked increase in the expression of interleukin-6 (IL-6) and significantly decreased expression of immunocompetent cell marker CD14 and of insulin receptor substrate 1 (IRS1) in obese compared with non-obese subjects. 
The expression of other studied genes was not significantly different in obese compared with lean subjects (Table 2).

Depot-specific differences in the expression of genes in obese and lean subjects: comparison of subcutaneous and visceral adipose tissue and isolated adipocytes from both depots

The overview of the depot-specific relative differences in the expression of the studied genes is summarized in Table 3. The expression of an immunocompetent cells marker CD45 was significantly higher in SAT than in SAT isolated adipocytes in obese, but not in nonobese subjects. The expression of CD14 was significantly higher in adipocytes from both SAT and VAT than in whole tissues of both study groups. The expression of IL-6 was markedly higher in visceral adipocytes than in the VAT in both obese (40-fold) and non-obese group (20-fold). The expression of CCL3 was 13.6-fold higher in adipocytes from SAT than in adipocytes from VAT and 22.8-fold higher in SAT adipocytes than in whole SAT in obese subjects. The expression of CCL3 was 4-fold higher in SAT relatively to VAT in obese subjects. Neither of these relative differences in CCL3 expression was seen in non-obese group. IL1- $\beta$ expression was 25 -fold and 2.7 -fold higher in VAT adipocytes than in VAT in the obese and non-obese group, respectively. Leptin and leptin receptor expression was significantly higher in SAT and VAT than in respective adipocytes in the obese group. In non-obese group, the same results were found, except for lack of difference in the expression of leptin between adipocytes from VAT and whole VAT. The expression of SERPINE1 was 24-fold higher in SAT adipocytes than in VAT adipocytes in the obese group only.

\section{DISCUSSION}

We quantified expression of genes potentially involved in metabolic complications of obesity in SAT and VAT of morbidly obese and normal-weight subjects. We found that the 
presence of obesity and insulin resistance is associated with changes of the specific proinflammatory, lipogenic, adipogenic and insulin signaling resistance pathway genes with no preferable localization in SAT or VAT depot.

Previous clinical studies have demonstrated that VAT exhibits metabolically harmful profile more closely related to metabolic complications of obesity than SAT (Wajchenberg, 2000; Hotamisligil, 2003; Wagenknecht et al., 2003 and Freedland, 2004). Here we show that both SAT and VAT of obese subjects exhibit markedly increased expression of specific proinflammatory genes (CCL3 in the SAT vs. IL-6 in the VAT) relative to lean subjects. The exact source of proinflammatory cytokines within the adipose tissue (adipocytes vs. stromavascular fraction) is still not completely clear (Savage et al., 2001; McTernan et al., 2002; Weisberg et al., 2003 and Kusminski et al., 2005). Thus, we measured the expression of two immunocompetent cells markers in adipose tissue to assess whether increased adipose tissue infiltration by immunocompetent cells can explain increased IL-6 in VAT of obese. However, the expression of CD14 in VAT was decreased rather than increased and the expression of CD45 was unchanged in obese relative to lean group, indicating that IL-6 is probably expressed by adipocytes rather than by immunocompetent cells in obese (Coppack, 2001). Alternatively, higher secretory activity rather than increased number of macrophages in obese subjects could explain their increased proinflammatory genes expression in. This hypothesis, however, does not explain much higher expression of CCL3 in subcutaneous adipocytes relative to whole SAT from obese. Such a finding rather suggests that some of proinflammatory factors are highly expressed by adipocytes. In contrast, the lack of the expression of resistin and TNF- $\alpha$ in isolated adipocytes from both depots (resistin) and from VAT (TNF- $\alpha$ ) suggests their unitary extraadipocyte production by macrophages at least in the respective depot (Weisberg et al., 2003 and Kusminski et al., 2007). 
Overall, our present data do not confirm that VAT more actively contributes to proinflammatory and insulin resistant state of obese subjects relative to SAT as has been numerously demonstrated in some (Wajchenberg, 2000 and Wagenknecht et al., 2003), but not all (Abate et al., 1995 and Goodpaster and Kelley, 1998) previous studies. Furthermore, we do not confirm that increased infiltration of adipose tissue by macrophages is crucial for the development of proinflammatory state and insulin resistance. There might be an important crosstalk between adipocytes from both depots and other cell types and the production of many factors might be constitutive. We bear in mind that the observed upregulation of inflammation-related genes in adipocytes of obese subjects could be due to contamination of the isolated adipocytes by macrophages (Lee et al., 2005). This is, however, unlikely since all samples were subject to similar procedure.

Several genes involved in insulin signaling pathway presented altered expression in both adipose tissue depots from our obese patients, in conseptual agreement with the defective insulin-mediated glucose uptake by obese adipocytes reported earlier (Graham and Kahn, 2007, Kovacs et al., 2003). Here we show that both SAT and VAT of obese exhibit depotspecific alterations of expression of typical (e.i., GLUT4, IRS1) and less typical (e.i., PPARa) (Loviscach et al., 2000) genes involved in insulin signaling pathway.

As expected, the altered expression of critical elements of insulin-stimulated glucose uptake (GLUT4) and of lipogenic pathway (FASN) might be related to altered expression of transcriptional factors, such as SREBF1 (Griffin and Sul, 2004 and Im et al., 2007). Here we show that SREBF1 expression in SAT is reduced simultaneously with the expression of both GLUT4 and FASN suggesting that this transcriptional factor could play an important role in the regulation of expression of critical elements of glucose uptake and lipogenic pathway in adipose tissue of obese. The reduction of FASN and SREBF1 in the SAT of obese might 
contribute to the reduction of de novo lipogenesis in obese and thus contribute to the alterations in glucose metabolism and excess in other cell types and tissues.

The explanation of increases of some genes and decreases of the others when comparing isolated adipocytes and adipose tissue may lie in the predominant functional participation of the product of specific gene in processes localizated to adipocyte itself or to the tissue in general. The expression of genes in adipose tissue may be influenced by the varying numbers of cell types present in the tissue, whereas the expression of genes in isolated adipocytes may be influenced not only by the local or systemic pathophysiological changes but possibly also by the isolation procedure. Bearing that in mind, we believe that comparing whole adipose tissue and isolated adipocytes is an important tool to specify the predominant location of gene expression within the fat for future studies.

We are aware, that our study has several limitations. The first one is a relatively low number of subjects included and the presence of impaired fasting glucose in some of the obese patients. These facts together with a huge variance of the data may partly explain some of the unexpected findings in obese vs. non obese subjects (e.g., unchanged expression of leptin, TNF- $\alpha$ in obese). Secondly, we are aware that the procedure for isolating adipocytes could trigger dramatic changes in expression of mRNA, especially the induction of genes encoding inflammatory mediators, chemokines and transcription factors including in the inflammatory response (Ruan et al., 2003 and Fain et al., 2004). Finally, it is noteworthy that the expression of the gene is not equal to protein production.

We conclude that both SAT and VAT depots of obese subjects exhibit alterations in the expression of specific proinflammatory, adipogenic, insulin signaling pathway and lipogenic genes possibly contributing to proinflammatory and insulin resistance state and consequently to metabolic complications of obesity. Adipocytes are at least partly responsible for the 
expression of proinflammatory cytokines in adipose tissue. The expression of specific genes significantly quantitatively differs between isolated adipocytes and whole adipose tissue.

\section{Acknowledgements}

Supported by IGA MHCR grant No. 8302-5. We thank Ales Horinek for technical assistance. 


\section{REFERENCES}

Abate, N., Garg, A., Peshock, R.M., Stray-Gundersen, J. and Grundy, S.M., 1995. Relationships of generalized and regional adiposity to insulin sensitivity in men. J. Clin. Invest. 96, pp. 88-98.

Bastard, J.P., Maachi, M., Lagathu, C., Kim, M.J., Caron, M., Vidal, H., Capeau, J. and Feve, B., 2006. Recent advances in the relationship between obesity, inflammation, and insulin resistance. Eur. Cytokine Netw. 17, pp. 4-12.

Coppack, S.W., 2001. Pro-inflammatory cytokines and adipose tissue. Proc. Nutr. Soc. 60, pp. 349-356.

Dubois, S.G., Heilbronn, L.K., Smith, S.R., Albu, J.B., Kelley, D.E. and Ravussin, E., 2006. Decreased expression of adipogenic genes in obese subjects with type 2 diabetes. Obesity (Silver Spring). 14, pp. 1543-1552.

Eckel, R.H., Grundy, S.M. and Zimmet, P.Z., 2005. The metabolic syndrome. Lancet 365, pp. $1415-1428$.

Fain, J.N., Madan, A.K., Hiler, M.L., Cheema, P. and Bahouth, S.W., 2004. Comparison of the release of adipokines by adipose tissue, adipose tissue matrix, and adipocytes from visceral and subcutaneous abdominal adipose tissues of obese humans. Endocrinology 145, pp. $2273-2282$. 
Fasshauer, M., Klein, J., Neumann, S., Eszlinger, M. and Paschke, R., 2001. Tumor necrosis factor alpha is a negative regulator of resistin gene expression and secretion in 3T3-L1 adipocytes. Biochem. Biophys. Res. Commun. 288, pp. 1027-1031.

Frayn, K.N. and Coppack S.W., 1992. Insulin resistance, adipose tissue and coronary heart disease. Clin. Sci. (Lond). 82, pp. 1-8.

Freedland, E.S., 2004. Role of a critical visceral adipose tissue threshold (CVATT) in metabolic syndrome: implications for controlling dietary carbohydrates: a review. Nutr. Metab. (Lond). 1, pp. 12.

Fujita, K., Nishizawa, H., Funahashi, T., Shimomura, I. and Shimabukuro, M., 2006. Systemic oxidative stress is associated with visceral fat accumulation and the metabolic syndrome. Circ. J. 70, pp. 1437-1442.

Goodpaster, B.H. and Kelley, D.E., 1998. Role of muscle in triglyceride metabolism. Curr. Opin. Lipidol. 9, pp. 231-236.

Graham, T.E. and Kahn, B.B., 2007. Tissue-specific alterations of glucose transport and molecular mechanisms of intertissue communication in obesity and type 2 diabetes. Horm. Metab. Res. 39, pp. 717-721.

Griffin, M.J. and Sul, H.S., 2004. Insulin regulation of fatty acid synthase gene transcription: roles of USF and SREBP-1c. IUBMB Life. 56, pp. 595-600. 
Hotamisligil, G.S., Shargill, N.S. and Spiegelman, B.M., 1993. Adipose expression of tumor necrosis factor-alpha: direct role in obesity-linked insulin resistance. Science 259, pp. 87-91.

Hotamisligil, G.S., 2003. Inflammatory pathways and insulin action. Int. J. Obes. Relat. Metab. Disord. 27, pp. S53-55.

Im, S.S., Kwon, S.K., Kim, T.H., Kim, H.I. and Ahn Y.H., 2007. Regulation of glucose transporter type 4 isoform gene expression in muscle and adipocytes. IUBMB Life. 59, pp. 134-145.

Kolak, M., Yki-Järvinen, H., Kannisto, K., Tiikkainen, M., Hamsten, A., Eriksson, P. and Fisher, R.M., 2007. Effects of chronic rosiglitazone therapy on gene expression in human adipose tissue in vivo in patients with type 2 diabetes. J. Clin. Endocrinol. Metab. 92, pp. $720-724$.

Kovacs, P., Hanson, R.L., Lee, Y.H., Yang, X., Kobes, S., Permana, P.A., Bogardus, C. and Baier, L.J., 2003. The role of insulin receptor substrate-1 gene (IRS1) in type 2 diabetes in Pima Indians. Diabetes 52, pp. 3005-3009.

Kremen, J., Dolinkova, M., Krajickova, J., Blaha, J., Anderlova, K., Lacinova, Z., Haluzikova, D., Bosanska, L., Vokurka, M., Svacina, S. and Haluzik, M., 2006. Increased subcutaneous and epicardial adipose tissue production of proinflammatory cytokines in cardiac surgery patients: possible role in postoperative insulin resistance. J. Clin. Endocrinol. Metab. 91, pp. 4620-4627. 
Kusminski, C.M., da Silva, N.F., Creely, S.J., Fisher, F.M., Harte, A.L., Baker, A.R., Kumar, S. and McTernan, P.G., 2007. The in vitro effects of resistin on the innate immune signaling pathway in isolated human subcutaneous adipocytes. J. Clin. Endocrinol. Metab. 92, pp. 270276.

Kusminski, C.M., McTernan, P.G. and Kumar, S., 2005. Role of resistin in obesity, insulin resistance and Type II diabetes. Clin. Sci. (Lond). 109, pp. 243-256.

Lee, Y.H., Nair, S., Rousseau, E., Allison, D.B., Page, G.P., Tataranni, P.A., Bogardus, C. and Permana, P.A., 2005. Microarray profiling of isolated abdominal subcutaneous adipocytes from obese vs non-obese Pima Indians: increased expression of inflammation-related genes. Diabetologia 48, pp. 1776-1783.

Loviscach, M., Rehman, N., Carter, L., Mudaliar, S., Mohadeen, P., Ciaraldi, T.P., Veerkamp, J.H. and Henry, R.R., 2000. Distribution of peroxisome proliferator-activated receptors (PPARs) in human skeletal muscle and adipose tissue: relation to insulin action. Diabetologia 43, pp. 304-311.

Matsuzawa, Y., 2006. The metabolic syndrome and adipocytokines. FEBS Lett. 580, pp. 2917-2921.

Matthews, D.R., Hosker, J.P., Rudenski, A.S., Naylor, B.A., Treacher, D.F. and Turner, R.C., 1985. Homeostasis model assessment: insulin resistance and beta-cell function from fasting plasma glucose and insulin concentrations in man. Diabetologia 28, pp. 412-419. 
McTernan, P.G., McTernan, C.L., Chetty, R., Jenner, K., Fisher, F.M., Lauer, M.N., Crocker, J., Barnett, A.H. and Kumar, S., 2002. Increased resistin gene and protein expression in human abdominal adipose tissue. J. Clin. Endocrinol. Metab. 87, pp. 2407-2410.

Ruan, H., Zarnowski, M.J., Cushman, S.W. and Lodish, H.F., 2003. Standard isolation of primary adipose cells from mouse epididymal fat pads induces inflammatory mediators and down-regulates adipocyte genes. J. Biol. Chem. 278, pp. 47585-47593.

Savage, D.B., Sewter, C.P., Klenk, E.S., Segal, D.G., Vidal-Puig, A., Considine, R.V. and O'Rahilly, S., 2001. Resistin / Fizz3 expression in relation to obesity and peroxisome proliferator-activated receptor-gamma action in humans. Diabetes 50, pp. 2199-2202.

Tan, G.D., Debard, C., Funahashi, T., Humphreys, S.M., Matsuzawa, Y., Frayn, K.N., Karpe, F. and Vidal, H., 2005. Changes in adiponectin receptor expression in muscle and adipose tissue of type 2 diabetic patients during rosiglitazone therapy. Diabetologia 48, pp. 15851589.

Wagenknecht, L.E., Langefeld, C.D., Scherzinger, A.L., Norris, J.M., Haffner, S.M., Saad, M.F. and Bergman, R.N., 2003. Insulin sensitivity, insulin secretion, and abdominal fat: the Insulin Resistance Atherosclerosis Study (IRAS) Family Study. Diabetes 52:2490-2496.

Wajchenberg, B.L., 2000. Subcutaneous and visceral adipose tissue: their relation to the metabolic syndrome. Endocr. Rev. 21, pp. 697-738. 
Weisberg, S.P., McCann, D., Desai, M., Rosenbaum, M., Leibel, R.L. and Ferrante, A.W. Jr., 2003. Obesity is associated with macrophage accumulation in adipose tissue. J. Clin. Invest. 112, pp. 1796-1808.

Zhang, Y., Proenca, R., Maffei, M., Barone, M., Leopold, L. and Friedman, J.M., 1994. Positional cloning of the mouse obese gene and its human homologue. Nature 372, pp. 425432. 
TABLE 1. Clinical, hormonal and metabolic characteristics of the study subjects.

\begin{tabular}{|l|l|l|}
\hline & Controls $(\mathrm{n}=12)$ & Obese $(\mathrm{n}=12)$ \\
\hline Age $(\mathrm{yr})$ & $48.9 \pm 2.6$ & $44.9 \pm 2.7$ \\
\hline Body mass index $\left(\mathrm{kg} / \mathrm{m}^{2}\right)$ & $23.6 \pm 0.7$ & $41.0 \pm 1.9^{*}$ \\
\hline C-reactive protein $(\mathrm{mg} / \mathrm{l})$ & $5.8 \pm 1.5$ & $21.9 \pm 4.8^{*}$ \\
\hline Fasting serum insulin $(\mathrm{mIU} / \mathrm{l})$ & $9.6 \pm 1.7$ & $38.8 \pm 10.4^{*}$ \\
\hline Fasting serum glucose $(\mathrm{mmol} / \mathrm{l})$ & $4.2 \pm 0.3$ & $6.5 \pm 0.7^{*}$ \\
\hline HOMA-IR & $2.0 \pm 0.4$ & $11.9 \pm 2.9^{*}$ \\
\hline HbAlc $(\%)$ & $3.9 \pm 0.1$ & $4.3 \pm 0.5$ \\
\hline Cholesterol total $(\mathrm{mmol} / \mathrm{l})$ & $5.2 \pm 0.3$ & $4.3 \pm 0.2$ \\
\hline Triacylglycerides $(\mathrm{mmol} / \mathrm{l})$ & $1.2 \pm 0.2$ & $1.6 \pm 0.2$ \\
\hline Leptin $(\mathrm{ng} / \mathrm{ml})$ & $12.9 \pm 2.2$ & $48.4 \pm 4.7^{*}$ \\
\hline Resistin $(\mathrm{ng} / \mathrm{ml})$ & $7.9 \pm 1.1$ & $10.3 \pm 1.2$ \\
\hline Adiponectin $(\mu \mathrm{g} / \mathrm{ml})$ & $21.9 \pm 2.1$ & $13.3 \pm 1.5^{*}$ \\
\hline
\end{tabular}

Values represent mean \pm SEM.

$* \mathrm{p}<0.05$ vs. non-obese controls. 
TABLE 2. Fold changes of the gene expression levels in subcutaneous and visceral adipocytes and subcutaneous and visceral whole adipose tissue from obese $(n=12)$ relative to normal-weight subjects $(n=12)$. The mean value of the expression of the gene of interest in normal-weight subjects was taken as $100 \%$ or 1.0 , respectively. 
TABLE 3. Comparison of the relative expression of studied genes in subcutaneous isolated adipocytes vs. visceral isolated adipocytes, in subcutaneous isolated adipocytes vs. whole subcutaneous adipose tissue, in visceral isolated adipocytes vs. whole visceral adipose tissue and in whole subcutaneous adipose tissue vs. whole visceral adipose tissue from obese (n = 12) and normal-weight subjects $(n=12)$. 
TABLE 2. Fold changes of the gene expression levels in subcutaneous and visceral adipocytes and subcutaneous and visceral whole adipose tissue from obese $(n=12)$ relative to normal-weight subjects $(n=12)$. The mean value of the expression of the gene of interest in normal-weight subjects was taken as $100 \%$ or 1.0 , respectively.

\begin{tabular}{|c|c|c|c|c|c|c|c|c|c|}
\hline \multirow[t]{2}{*}{$\begin{array}{l}\text { gene } \\
\text { symbol }\end{array}$} & \multirow[t]{2}{*}{ gene name } & \multicolumn{2}{|c|}{$\begin{array}{l}\text { Subcutaneous } \\
\text { adipocytes }\end{array}$} & \multicolumn{2}{|c|}{ Visceral adipocytes } & \multicolumn{2}{|c|}{$\begin{array}{l}\text { Whole subcutaneous } \\
\text { adipose tissue }\end{array}$} & \multicolumn{2}{|c|}{$\begin{array}{l}\text { Whole visceral } \\
\text { adipose tissue }\end{array}$} \\
\hline & & $\begin{array}{l}\text { fold } \\
\text { change }\end{array}$ & $\begin{array}{l}\text { t-test } \\
\text { (P value) }\end{array}$ & $\begin{array}{l}\text { fold } \\
\text { change }\end{array}$ & $\begin{array}{l}\text { t-test } \\
\text { (P value) }\end{array}$ & $\begin{array}{l}\text { fold } \\
\text { change }\end{array}$ & $\begin{array}{l}\text { t-test } \\
\text { (P value) }\end{array}$ & $\begin{array}{l}\text { fold } \\
\text { change }\end{array}$ & $\begin{array}{l}\text { t-test } \\
\text { (P value) }\end{array}$ \\
\hline ADIPOQ & adiponectin & 1.04 & 0.82 & 0.70 & 0.01 & 0.95 & 0.55 & 0.82 & 0.39 \\
\hline GHRL & ghrelin/obestatin preprohormone & 1.98 & 0.53 & 3.8 & 0.29 & 1.37 & 0.21 & 1.24 & 0.39 \\
\hline LEP & leptin & 1.00 & 0.31 & 1.06 & 0.31 & 1.48 & 0.11 & 1.50 & 0.09 \\
\hline ADIPOR1 & adiponectin receptor 1 & 0.63 & 0.38 & 0.75 & 0.38 & 1.17 & 0.42 & 1.09 & 0.74 \\
\hline ADIPOR2 & adiponectin receptor 2 & 0.77 & 0.35 & 0.99 & 0.65 & 0.87 & 0.39 & 1.12 & 0.48 \\
\hline LEPR & leptin receptor & 2.65 & 0.68 & 0.58 & 0.18 & 1.32 & 0.63 & 1.27 & 0.59 \\
\hline RETN & resistin & UD & & UD & & 2.49 & 0.16 & 0.99 & 0.98 \\
\hline PBEF1 & visfatin & 0.61 & 0.25 & 0.77 & 0.17 & 1.19 & 0.54 & 0.86 & 0.53 \\
\hline IL1B & interleukin 1 , beta & 0.58 & 0.91 & 19.5 & 0.71 & 0.89 & 0.64 & 2.09 & 0.11 \\
\hline IL6 & interleukin 6 & 0.51 & 0.68 & 6.77 & 0.20 & 0.48 & 0.48 & 3.58 & 0.04 \\
\hline
\end{tabular}




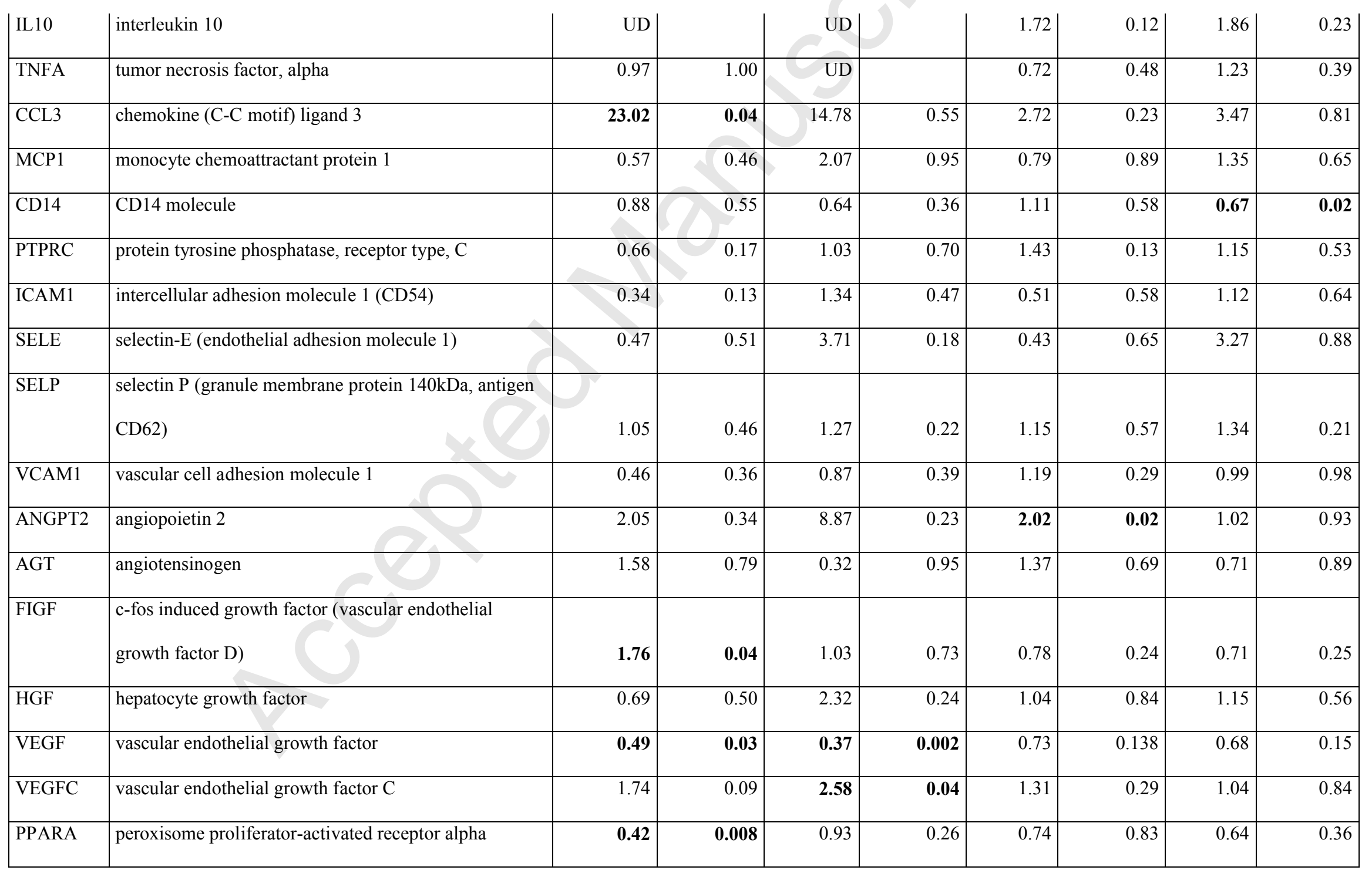




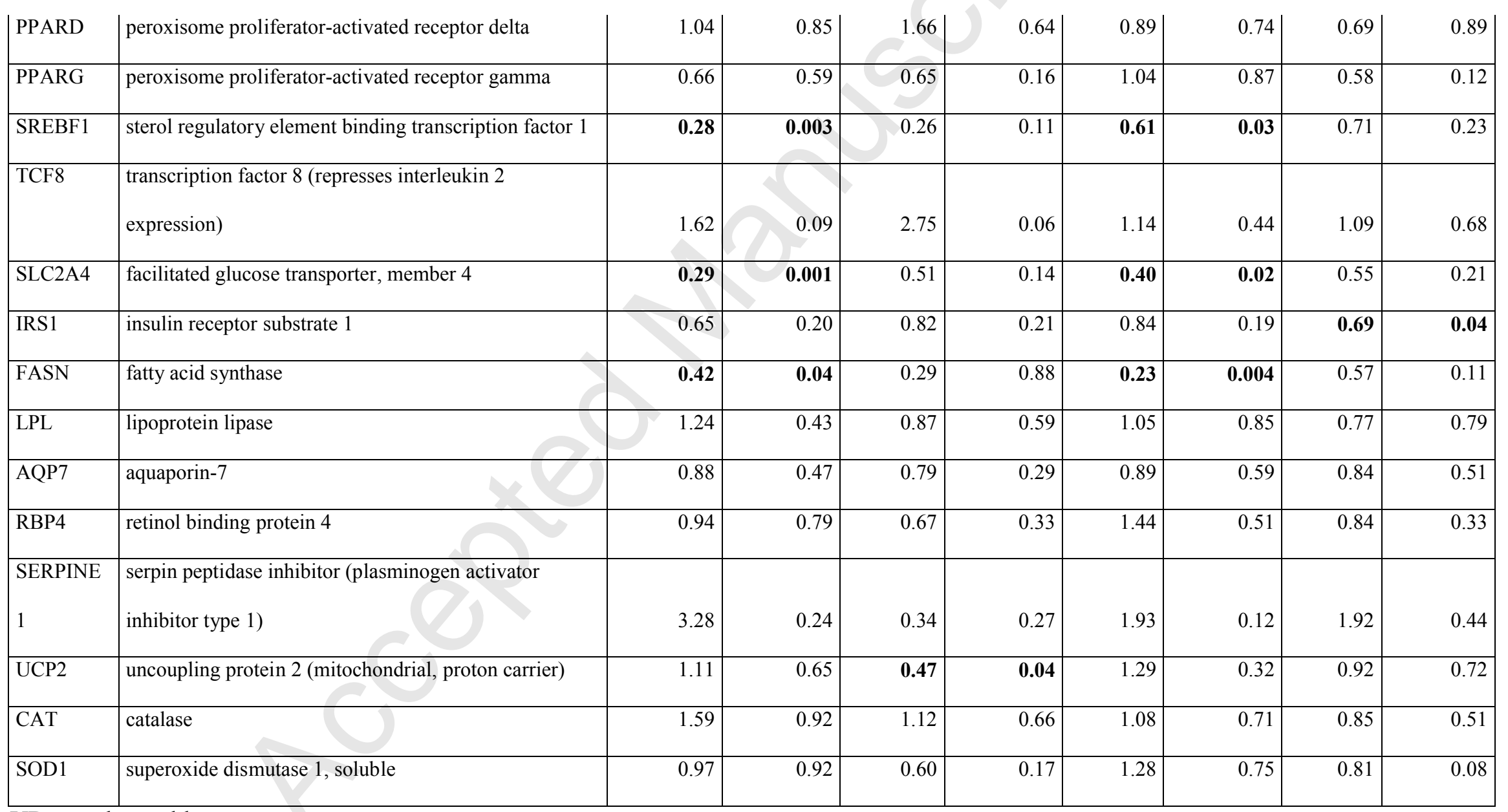

$\mathrm{UD}=$ undetectable 
TABLE 3. Comparison of the relative expression of studied genes in subcutaneous isolated adipocytes vs. visceral isolated adipocytes, in subcutaneous isolated adipocytes vs. whole subcutaneous adipose tissue, in visceral isolated adipocytes vs. whole visceral adipose tissue and in whole subcutaneous adipose tissue vs. whole visceral adipose tissue from obese $(n=12)$ and normal-weight subjects $(n=12)$.

\begin{tabular}{|c|c|c|c|c|c|c|c|c|c|}
\hline Gene & Function & obese $(n=12)$ & & & & control subjec & ts $(n=12)$ & & \\
\hline & & $\begin{array}{l}\text { subcutaneous } \\
\text { adipocytes/ } \\
\text { visceral } \\
\text { adipocytes }\end{array}$ & $\begin{array}{l}\text { subcutaneous } \\
\text { adipocytes/ } \\
\text { subcutaneous } \\
\text { adipose } \\
\text { tissue }\end{array}$ & \begin{tabular}{|l|} 
visceral \\
adipocytes/ \\
visceral \\
adipose \\
tissue
\end{tabular} & $\begin{array}{l}\text { subcutaneous } \\
\text { adipose } \\
\text { tissue/ } \\
\text { visceral } \\
\text { adipose } \\
\text { tissue }\end{array}$ & \begin{tabular}{|l|} 
subcutaneous \\
adipocytes/ \\
visceral \\
adipocytes
\end{tabular} & \begin{tabular}{|l|} 
subcutaneous \\
adipocytes/ \\
subcutaneous \\
adipose \\
tissue
\end{tabular} & $\begin{array}{l}\text { visceral } \\
\text { adipocytes/ } \\
\text { visceral } \\
\text { adipose } \\
\text { tissue }\end{array}$ & $\begin{array}{l}\text { subcutaneous } \\
\text { adipose } \\
\text { tissue/ } \\
\text { visceral } \\
\text { adipose } \\
\text { tissue }\end{array}$ \\
\hline ADIPOQ & hormone, energy metabolism, insulin sensitivity & - & $0.53 *$ & $0.56^{*}$ & & & $0.49^{*}$ & & \\
\hline GHRL & hormone, energy metabolism & & & & & & & $5.20 *$ & \\
\hline LEP & hormone, energy metabolism, insulin sensitivity & $1.43^{*}$ & $0.41 * * *$ & $0.39 * * *$ & & $1.51 *$ & $0.61 *$ & $0.56^{*}$ & $1.37 *$ \\
\hline ADIPOR1 & $\begin{array}{l}\text { receptor, molecular and biological function } \\
\text { unclassified }\end{array}$ & & $0.19 *$ & $0.26^{*}$ & & & $0.35^{*}$ & $0.37 *$ & \\
\hline ADIPOR2 & $\begin{array}{l}\text { receptor, molecular and biological function } \\
\text { unclassified }\end{array}$ & & $3.21 *$ & $3.27 *$ & & & $3.64 *$ & $3.69 *$ & \\
\hline LEPR & receptor, molecular and biological function & & $0.64 *$ & $0.35^{*}$ & & $0.33^{*}$ & $0.32 * * *$ & & $0.81 *$ \\
\hline
\end{tabular}




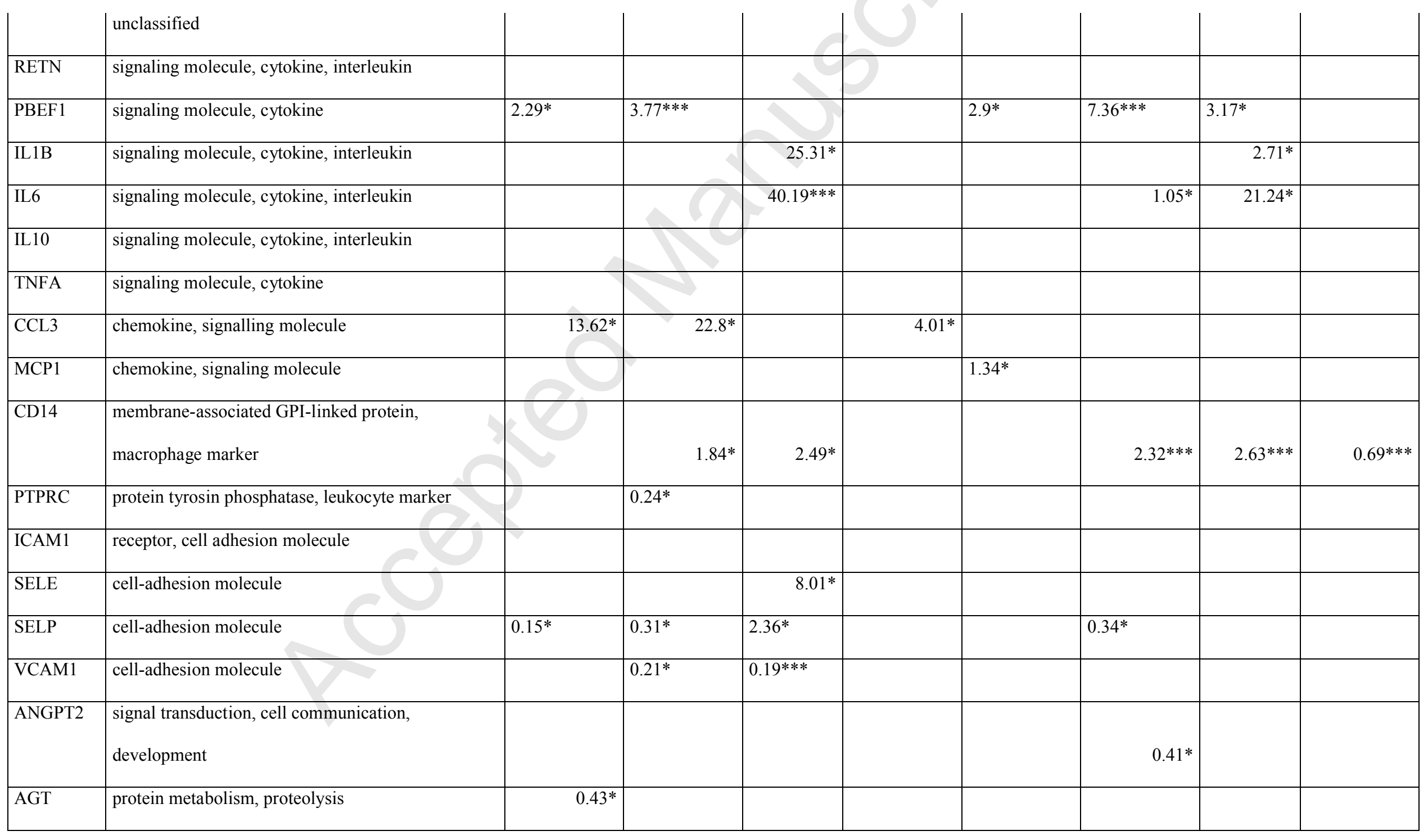




\begin{tabular}{|c|c|c|c|c|c|c|c|c|}
\hline FIGF & signaling molecule, growth factor & & & & $2.46^{*}$ & $0.23 * * *$ & & $2.26^{*}$ \\
\hline HGF & signaling molecule, growth factor & & $0.55^{*}$ & & & & & \\
\hline VEGF & signaling molecule, growth factor & $1,88 * * *$ & $1.84 * * *$ & & & $2.72 * * *$ & $1.97 *$ & \\
\hline VEGFC & signaling molecule, growth factor & & $0.27 * * *$ & $0.50 *$ & & $0.19 * * *$ & $0.21 *$ & \\
\hline PPARA & transcription factor, nuclear hormone receptor & & & 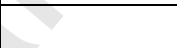 & & $1.81 *$ & & \\
\hline PPARD & transcription factor, nuclear hormone receptor & & & & & $0.35^{*}$ & & $1.44 *$ \\
\hline PPARG & transcription factor, nuclear hormone receptor & & & & $1.86^{*}$ & & & \\
\hline SREBF1 & $\begin{array}{l}\text { transcription factor, regulation of lipid, fatty acid } \\
\text { and steroid metabolism }\end{array}$ & & $1.63 *$ & & & $3.54 *$ & & \\
\hline SLC2A4 & carbohydrate transporter, carbohydrate metabolism & & & & & & & \\
\hline IRS1 & $\begin{array}{l}\text { glucose homeostasis, intracellular insulin signaling } \\
\text { cascade }\end{array}$ & 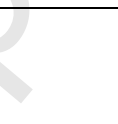 & $2.19^{*}$ & $2.74^{*}$ & & $2.83 * * *$ & $2.30 * * *$ & \\
\hline FASN & synthase, fatty acid metabolism & & $2.51 *$ & & & & & \\
\hline LPL & $\begin{array}{l}\text { hydrolase, lipase, lipid, fatty acid and steroid } \\
\text { metabolism }\end{array}$ & & $0.59 *$ & $1.66^{*}$ & & $0.52 * * *$ & & \\
\hline RBP4 & $\begin{array}{l}\text { transfer/carrier protein, coenzyme and prosthetic } \\
\text { group metabolism }\end{array}$ & & & & $2.43 *$ & $1.63 *$ & & \\
\hline SERPINE & serine protease inhibitor & $24.29 *$ & & & $2.44^{*}$ & & & \\
\hline
\end{tabular}




\begin{tabular}{|l|l|l|l|l|l|l|l|}
1 & & & & & \\
\hline UCP2 & mitochondrial carrier protein & & $0.24^{* * *}$ & $0.49^{* * *}$ & & $0.25^{* * *}$ & $0.28^{* * *}$ \\
\hline CAT & oxidoreductase, peroxidase & & & & & & \\
\hline SOD1 & oxidoreductase & & & & & & \\
\hline
\end{tabular}

$* \mathrm{p}<0.05$ vs. localisation

*** $\mathrm{p}<0.005$ vs. localisation

Free fields $=$ not significant 